\title{
Nanoagroparticles emerging trends and future prospect in modern agriculture system
}

\author{
Syed Baker ${ }^{\mathrm{a}}$, Tatiana Volova ${ }^{\mathrm{b}}$, Svetlana V. Prudnikova ${ }^{\mathrm{c}}$, S. Satish ${ }^{\mathrm{d}}$, Nagendra Prasad M.N. ${ }^{\mathrm{e}}$
}

a Laboratory of Biotechnology of New Materials, Siberian Federal University, Svobodnyy pr., 79, Krasnoyarsk 660041, Siberia, Russian Federation

b Institute of Biophysics of Russian Academy of Science, Russian Federation

c Siberian Federal University, School of Fundamental Biology and Biotechnology, Russian Federation d Bio-nantechnological Laboratory, Department of Studies in Microbiology, Manasagangotri, University of Mysore, Mysore 570006, India

e Department of Biotechnology, Sri Jayachamarajendra College of Engineering, JSS Science and Technology University, JSS Technical Institutional Campus, Mysore

570006, India

Keywords: Nanoparticles-agriculture, Nanoagroparticles, Nanoherbicides, Nanopesticides, Nanobiosensing, Soil fertility

\section{ABSTRACT}

Increment of technical knowledge has remarkably uplifted logical thinking among scientific communities to shape the theoretical concepts into near product-oriented research. The concept of nanotechnology has overwhelmed almost all forms of lives and has traded its applications in myriad fields. Despite rapid expansion of nanotechnology, sustainable competitions still do exist in the field of agriculture. In current scenario, agriculture is a manifestation demand to provide adequate nutrition for relentless growing global population. It is estimated that nearly one-third of the global crop production is destroyed annually. The loss owes to various stresses such as pest infestation, microbial pathogens, weeds, natural calamities, lack of soil fertility and much more. In order to overcome these limitations, various technological strategies are implemented but a majority of these have their own repercussions. Hence there is a scrawling progress on the evaluation of nanoparticles into agriculture sector which can reform the modern agricultural system. Applications of these nanomaterials can add tremendous value in the current scenario of a global food scarcity. Nanotechnology can address the adverse effects posed by the abundant use of chemical agrochemicals which are reported to cause biomagnification in an ecosystem. Based on these facts and consideration, present review envisages on nanoparticles as nanoherbicides, nanopesticides, onsite detection agro-pathogens and nanoparticles in post harvest management. The review also elucidates on the importance of nanoparticles in soil fertility, irrigation management and its influence on improving crop yield. With scanty reports available on nanotechnology in agriculture system, present review attributes toward developing nanoagroparticles as the future prospect which can give new facelift for existing agriculture system.

\section{Introduction}

Increment of technical knowledge has remarkably uplifted logical thinking among scientific communities to shape the theoretical concepts into near product-oriented research. One such imagination of Feynman was "There's plenty of room at the bottom" which resulted in recognition and emergence of nanotechnology as one of the key emerging technologies of the decades (Feynman, 1960). Introduction of nanotechnology in different sectors has significantly contributed in enhancement of applicative properties (Nikalje, 2015). One of the important aspects in nanotechnology is evaluation of nanomaterials.

Use of nanomaterials has led to a new era, the nano-revolution which unfolds maneuvering particles with at least one dimension at nano-scale (Syed et al., 2016). Nanomaterials are considered as particles of the century and have drawn unequivocal attention (Zhao et al., 2014). These nanomaterials have traded their progress in various sectors due to their 
size-structure dependent physicochemical properties and emerged as the most inspiring materials in technical world (Porchezhiyan and Noorjahan, 2016). Nanomaterials with minuscule size bear high reactivity owing to the large surface plasmon resonance which significantly advances their analytical abilities (Baker et al., 2015). Despite rapid expansion of nanotechnology, sustainable competitions still do exist in field of agriculture sector. In the current scenario, the agricultural sector must promise adequate nutrition for a rapidly expanding global population (Mba et al., 2012). Unfortunately, it is estimated that nearly one third of the global crop production goes waste on an annual basis during the span of production till consumption. In order to cope up with this and improve the post-harvest standards, various technological solutions are emerging. One of such progress has initiated with implementation of nanomaterials based products toward reforming the modern agriculture (Sekhon, 2014). Lately, much efforts have been devoted to involve nanoparticles in the agricultural sector which is expected to transform the modern agricultural practices (Fraceto et al., 2016). In current scenario, agriculture community is facing wide range of challenges viz., stagnation of yield, destruction of crops due to pest attack, loss of soil fertility, inadequate water, fluctuating climatic conditions and contamination of soil due to environmental pollutants which has led to severe loss (Pouratashi and Iravani, 2012). In order to address these difficulties, rational design and innovative approaches are highly essential.

Nanoagroparticles are nano-sized particles which are designed to alleviate the problems related to the agriculture sector (Parisi et al., 2015). These nanoagroparticles can act efficiently as fungicides, insecticides, herbicides, pesticides and also as plant growth promoting factors (Fig. 1). But one of the major concern is the production of facile nanoparticles without any usage of toxic elements during synthesis. Most of the conventional methods are often bound with various implications such as generation of high heat, requires toxic elements for synthesis, requires sophisticated facility etc. (Kavitha et al., 2013). Hence scientific communities are engaged in developing eco-friendly and facile route to synthesize nanoparticles with desired properties. One such area is employing biogenic sources for synthesis of nanoparticles. The biogenic sources includes plants, microbes or their products which act as reductive agents and mediate the synthesis and stabilize nanoparticles. Some of the reported biogenic sources are represented in Table 1.

\section{Physicochemical properties of nanoagroparticles}

The physicochemical properties of nanoagroparticles impart enhanced beneficial characteristics in comparison to their bulk counterparts (Syed et al., 2016). The particle size of nanoagroparticles plays an important role in biological applications. Marginal decrease in size eventually increases surface area to volume ratio which results in enhanced activity (Baker and Satish, 2012). Hence minimal amount of nanoagroparticles are sufficient to achieve desired activity. The surface properties of nanomaterials also define its behavior which are essential for conjugation or tailoring the nanomaterials with different functional moieties to enhance the specific activity. Diverse classes and chemistry including the composition and crystalline nature of the nanoagroparticles are also reported to influence the activity (Kavitha et al., 2013).

For instances, Zinc forms a vital component of many enzymes which aid in metabolic process of different crops and enhances the growth and development in plant system (Overbeck et al., 2008). Similarly, use of copper in the agriculture can be traced down since 17th century, which was used against phytopathogens (Usman et al., 2013). Further, magnesium plays pivotal role in photosynthesis. Studies also report that deficiency of magnesium can lead to poor growth which drastically affect the crop yield (Guo et al., 2016). Hence, many more elementary components are evaluated for different prospect in agriculture and the implementation of nanomaterials of these components, has resulted in enhanced and untold beneficial characteristics. A glimpse of different applications has been provided in the later part of the review.

\section{Parameters influencing the activity of nanoagroparticles}


Different parameters determine the efficacy of nanoagroparticles. In order to achieve maximum activity on targeted pest, factors like solubility, origin and synthesis protocols play important roles. It has been reported that most of the agrochemicals are poorly soluble in water and are only soluble in solvent. These solvents are often toxic and add deleterious impact on the ecosystem (Ishaaya et al., 2007). In case of nanoagroparticles, they are soluble in water and moreover, their solubility can be tuned accordingly by increasing or decreasing the hydrophilic groups during the synthesis process (Baker and Satish, 2012). The synthesis protocols greatly influences the toxicity of the nanoagroparticles and use of toxic elements during chemical synthesis process can lead various health implications and environmental concerns (Kavitha et al., 2013). Hence, scientific communities are engaged in developing rational design to synthesize nanoagroparticles which are based on green principles by employing biogenic sources as mentioned earlier. During biogenic process of synthesis, different bioactive components acts as reducing and stabilizing agents which are regarded as safe components and shield or modulate the toxic effects (Syed et al., 2016). According to Baker et al. (2013b), some of the reported compounds responsible for synthesis are flavonoids, tannins, terpenoids, saponins, phenols and derivatives with few structures illustrated in Fig. 2. These bioactive compounds are compatible with the agricultural crops and have minimal toxic impact. In agriculture, in order to increase in the crop yields various harmful chemicals are widely used.

The chemically derived agricultural products are bound with myriad implications for instance, they usually unable to reach their target sites owing to chemical leaching, degradation by microbes and hydrolysis which results in repeated or over usage of the chemicals thus affecting the soil fertility and water contamination (Mishra et al., 2014). Perusal of scientific literatures envisage myriad nanoparticles evaluated in agriculture to test their efficacy and most of the reports suggests these nano sized structures have reported to be better advantageous for instance specific activity, targeted delivery, minimal quantity thus forming cost effective, high reactivity, encapsulation for slow release of nutrients and high stability under environmental conditions (Sekhon, 2014). Thus the present mini review comprises of scientific literatures which envisages the emerging role of nanoparticles in all spheres of modern agricultural system with different biological activities.

\section{Widely used nanoparticles in the agricultural system}

Nanoagroparticles can sustainably intensify the new paradigm in agriculture production and mitigate existing implications (Fraceto et al., 2016). Different classes of nanoparticles are used in agricultural system and type of nanoparticles depends on the mode of action or properties expecting to occur. Some of the widely used nanoparticles are silver, gold, copper, titanium, zinc, silica, aluminum, chitin nanoparticles, nano-clay and multiwalled carbon nanotubes, graphene nanoparticles, etc. (Sabir et al., 2014). The appropriate usage of nanoparticles is one of the desirable criteria for favorable agriculture activity. Different applications of nanoparticles are cited in Table 2. In agriculture, rational design and ideal characteristics of nanoagroparticles are highly essential such as specificity, solubility, non self-decomposition and control release of the component. In most cases, nanoagroparticles are often tagged or conjugated with carriers molecules which can lead to form an emulsion, polymerization, immobilized association, hydrogel and liposome-based products. The designed nanoagroparticles should be inexpensive, biocompatible, highly sensitive with minimal usage and maximum activity, minimal risk, potential to increase the crop productivity.

\section{Nanoagroparticles as potent antimicrobial agents against phytopathogens}

In agriculture sector, effective management of microbial infestation is an important factor and pathogenic microorganisms can cause deleterious effect on the crop productivity (Bhardwaj et al., 2014). In recent years, the emergence of drug-resistant microorganisms has posed a risk to mankind (Baker and Satish, 2015). Due to the inappropriate and over usage of microbicidal chemicals agents especially fungicides and bactericides has resulted toward development of 
novel resistant mechanisms among the disease causing pathogens which has resulted in the shortage of effective antimicrobial agents. Hence to combat these pathogens alternative strategies are highly desirable one such area gaining impute importance is the usage of nanoagroparticles. Nanoagroparticles owing to their size and functionalities can easily permit into the pathogenic cell wall and act efficiently with different mode of action for instance damage of cell membrane which results in loss of cellular contents, interacting with vital cellular components of pathogens causing disruption in metabolisms (Baker and Satish, 2012, 2015; Baker et al., 2015).

\section{Nanoagroparticles as potential fungicides}

Fungal diseases account for more than $70 \%$ of crop diseases compared to any other pathogens which significantly reduces the crop yield causing severe economic losses (Agrios, 2005). Some of the major crop species like rice, wheat, barley, cotton, groundnut and grapevine are susceptible to fungal attack (Dhekney et al., 2007). Hence in order to curb these fungal diseases, myriad conventional fungicides are in action. These chemical fungicides are reported to have deleterious effects on all forms of life in an ecosystem and can also target nonspecific living organisms (Patel et al., 2014). Development of combinatorial nanoagroparticles complex which comprises more than one active molecules can be one of the best-suited alternatives in combating the fungal pathogens (Mishra et al., 2014). Recent studies have well-demonstrated the use of nanoparticles as an effective agent against the array of fungal pathogens (Marziye Aboli et al., 2014). For instance, silver nanoparticles are found to be effective against rice blast disease caused by Magnaporthe grisea. Use of silver nanoparticles has minimized the usage of chemical fungicides such as isoprothiolane and azoxystrobin (Rabab and El-Shafey, 2013).Copper nanoparticles at $15 \mathrm{mg} / \mathrm{L}$ concentration was found to suppress the fungal pathogens Alternaria alternata and Botrytis cinerea (Ouda, 2014). Similarly, zinc oxide and magnesium oxide nanoparticles displayed significant inhibitory activity against spore germination of A. alternata, Fusarium oxysporum, Rhizopus stolonifer and Mucor plumbeus (Wani and Shah, 2012). Sulfur nanoparticles exhibited fungicidal efficacy against two phytopathogens, Fusarium solani and Venturia inaequalis which are responsible for wilt diseases and apple scab disease respectively. The study displayed the action of nanoparticles on cell wall which in turn disturbed cellular contents (Rao and Paria, 2013). According to Al- Othman et al. (2014), the effect of silver nanoparticles synthesized from Aspergillus terreus (KC462061) against aflatoxin producing isolates of Aspergillus flavus. Similarly, Parizi et al., 2014 studied the antifungal activity of magnesium oxide nanoparticles against F. oxysporum F. Sp. lycopersici which is reported to be the causal agent for wilt of tomato. Ramy and Ahmed (2013) investigated the in vitro antifungal effect of zinc oxide nanoparticles against F. oxysporum and Penicillium expansum. The study revealed concentration-dependent antifungal activity. The maximal inhibition of mycelial growth was found to be 77 and $100 \%$ against F. oxysporum and P. expansum, respectively at $12 \mathrm{mg} / \mathrm{L}$ $\mathrm{ZnO}$ nanoparticles. The $\mathrm{ZnO}$ nanoparticles also reduced mycotoxins production. The scanning electron microscopy revealed the deformation of mycelial growth treated with $\mathrm{ZnO}$ nanoparticles. Similarly, the silver nanoparticles synthesized by Aleo vera leaf extract exhibited antifungal activity against Rhizopus sp. and Aspergillus sp. The study reported inhibition of hyphal growth, detrimental effects on conidial germination and inhibition of normal budding process (Medda et al., 2014). The antifungal activity of zinc oxide ( $\mathrm{ZnO}$ ) and magnesium oxide $(\mathrm{MgO})$ nanoparticles was evaluated against A. alternata, F. oxysporum, R. stolonifer and $\mathrm{M}$. plumbeus. The results showed significant inhibition of spore germination at different silver nanoparticles concentration compared to control. The highest inhibition was observed by dose dependent-concentration (Wani and Shah, 2012). According to Ouda (2014), silver and copper nanoparticles displayed antifungal activity against A. alternata and B. cinerea. The study reported maximum inhibition of fungal hyphal growth at $15 \mathrm{mg} / \mathrm{L}$ concentration of silver nanoparticles. Microscopic observation revealed the damage of hyphae and conidia in presence 
of silver nanoparticles along with detrimental effect on sugar, protein, n-acetyl glucosamine and lipid content.

\section{Nanoagroparticles as potential nanobactericides}

The bactericidal properties of nanoparticles are well demonstrated with large number of scientific studies reporting the profound activity against array of pathogenic bacteria (Baker et al., 2015). According to the study conducted by Chowdhury et al. (2014), antibacterial activity was achieved with protein capped silver nanoparticles synthesized from Macrophomina phaseolina (Tassi) Goid. The study reported spherical silver nanoparticles with size ranging 5-40 $\mathrm{nm}$ which reported to have significant activity against normal (LBA4404) and multidrug resistant (LBA4404 MDR) Agrobacterium tumefaciens. Similarly, silver nanoparticles synthesized from Piper nigrum leaf and stem extracts exhibited antibacterial activity against phytopathogenic bacteria such as Citrobacter freundii and Erwinia cacticida (Paulkumar et al., 2014). Further, the antibacterial activity of phytosynthesized silver nanoparticles using aqueous extract of Helianthus tuberosus (sunroot tuber) against phyto pathogenic bacteria was studied by Aravinthan et al. (2015). The synthesized silver nanoparticles exhibited significant growth reduction of Ralstonia solanacearum and Xanthomonas axonopodis. According to Bhor et al. (2014), significant antibacterial activity against X. axonopodis pv. punicae was achieved using silver nanoparticles synthesized from Nephrolepis exaltata L. These reports clearly suggests the bactericidal potential of nanoparticles against phytopathogenic bacteria. There are sporadic literatures which report the efficiency of nanoparticles against human pathogenic bacteria but a less explorative research has been devoted against phytopathogens.

\section{Bionano-hybrid agroparticles against phytopathogens}

Bio-nano hybrid agroparticles are the complex nanosystem which relies on bioconjugation chemistry. Bioconjugation offers tremendous interest in biology for profound activities. Biomolecules can be tailored with various molecules but, lately, the conjugation of biomolecules with nanoparticles has become an important tool. Choice of the bioconjugation procedure depends strictly on physicochemical and biochemical properties of nanomaterials and bioactive molecules (Fig. 3). The interaction between nanoparticles and biomolecules is based on electrostatic forces and functional moieties on the nanoparticles which often leads to formation of functionalized nanoparticles in a reversible manner (Bagwea et al., 2003). The functional moieties can form hydrophobic interactions and covalent bonding (Baker and Satish, 2012, 2015). Therefore, such mechanisms are promising toward developing bionano-hybrid conjugates which have great potential in combating the drug resistant pathogens. For instance if a pathogen is resistant to antimicrobial agent then nanoparticles come into play and act efficiently against the pathogens with different mode of action.

\section{Nanoagroparticles as herbicides}

One of the serious threat during the farming is to get rid of undesirable weeds. The inundation growth of these weeds can be controlled by various chemical herbicides but most of these chemical based are reported to have residual toxicity even at the trace amount. Hence to avoid such situation, nanoherbicides are employed as safe tool. Nanoherbicides are reported to bear chemical stability, solubility, bioavailability, photodecomposition and soil sorption. Recent studies demonstrate formulation of nanoparticles coupled with active ingredients such as atrazine with poly (epsilon-caprolactone) nanoparticles as the carrier has enhanced the herbicidal activity (Pereira et al., 2014).

Further, reduced sorption of herbicides by encapsulation of chitosan and sodium triphosphate nanoparticles was achieved to minimize the toxicity compare to sole active component thus reducing risk to environment (Grillo et al., 2014). Recently, chitosan nanoparticles were cross-linked with disulfide bonds of diuron in order to control the release of 
herbicides based on the glutathione concentration. The results were successful in promoting plant growth and reduced the toxicity (Yu et al., 2015).

\section{Nanoagroparticles as alternative for pesticides}

Scientific studies and governing bodies across the globe has raised serious concern on usage of various chemically derived products especially pesticides. These compounds are of great concern. For example, clothionidin and thiomethoxam are neonicotinoids, highly toxic to bees and water ecosystem (Krupke et al., 2012). Many organophosphorous pesticides (OPPs) are highly toxic as they accumulate within adipose tissues in the body and cause biomagnification in higher tropical level organisms, therefore causing disruption in ecosystem and food chain (Gill and Garg, 2014). Some OPPs are able to percolate down to water bodies and contaminate drinking water (Baker et al., 2013c). Recently a commonly used OPPs the herbicide glyphosate was found toxic to humans (Guyton et al., 2015). Some of the OPPs can enter human diet and have been detected in breast milk. The severity of OPPs is rapidly expanding annually with an alarming number of poisonings worldwide with myriad effects from mild to significant including cancer, neurological effects, Parkinson disorder, respiratory diseases, fetal diseases, genetic disorders, infertility, and diabetes (Hu et al., 2015). In order to reduce the risk posed by various pesticides, there has been substantial research across the globe to remediate these pollutants with conventional methods like vitrification, excavation, addition of reactants, incineration and transportation of pollutants to offsite dumping yards (Singh et al., 2016). But the majority of these processes are expensive with the burden of approximately US \$25-50 billion annually (Kang, 2014). The process becomes deleterious especially in developing countries due to the paucity of economy and lack of scientific advances. To overwhelmed these adverse effects of pesticides different approaches have been implemented by using biopesticides formulation and green based agro chemicals. These eco-friendly based pesticides are not able to cope up the market demand and poor performance has forced scientific communities to develop alternative strategies. Hence introduction of nanomaterials based pesticides coupled with biological origin can address the negative aspect of the conventionally used pesticides (). In 2009 study conducted by Teodoro et al. (2010) reported insecticidal activity of nanostructured aluminum against major pests Sitophilus oryzae and Rhyzopertha dominica in stored food. The activity of nanoaluminum was significant with high mortality rates compared to commercial available insecticidal dust. Similarly, porous hollow silica nanoparticles were prepared which forms control delivery system of pesticides such as validamycin to enhance activity and reduce the toxicity compared to free validamycin. The activity of nanoparticles and their release rate mainly depend on $\mathrm{pH}$ and temperature of the dissolution medium (Liu et al., 2006). Similarly, the activity of silver and silver-zinc combined nanoparticles was assessed against Aphis nerii Boyer de Fonscolombe which resulted in mortality LC50 at 424.67 and $539.46 \mathrm{mg} / \mathrm{mL}$ respectively (Rouhani et al., 2012).

\section{Nanoagroparticles in soil improvement}

Soil fertility is an important factor in agriculture. During the course of natural calamities like the earthquake and landslides, soil tends to lose its fertility and strength (Gallagher and Mitchel, 2002). This liquefaction can be overcome by various techniques and in recent years, use of nano-structured materials are gaining popularity owing to its unique property like mechanical strength. Based on the scientific studies, nano-structured silica has the potential to remediate soil. Colloidal silica nanoparticles can easily disperse in aqueous solution and allow natural ground water and gradients to disperse uniformly thus strengthen soil (Diaz-Rodrigues et al., 2008). Apart from silica, use of bentonite and laponite nanoparticles is proved to have great potential in increasing the liquefaction resistant and high viscosity respectively (Gratchev et al., 2007).

\section{Nanoagro-sensors for detection and onsite diagnosis}


The early and onsite detection of diseases is one of the critical situation which can lead to avoid major destruction of crops. In most of the developing countries, farming has not scaled the modern system due to which many farmers are prone to face various challenges. One such major problem being encountered is onsite detection system. Biosensors have been used widely to monitor various analytes such as pesticides, toxins, pathogens and other pollutants (Fig. 4). These smart sensors are highly sensitive and can detect up to ppb level without the use of sophisticated laboratory and trained personnel's. Developing nanoagro-sensor exclusive for agriculture purpose is one of the emerging field which can aid the farmers to monitor the early diseases and contaminants. These sensors can minimize the burden and prevent economic losses by controlling the diseases (Liu et al., 2008). There are various literature attributing the progress of nanosensor in agriculture for instance detection of DDT using gold nanoparticles based sensor according to study conducted by Baker et al. (2013c). Similarly, the use of carbon nanotubes has become one of the most popular in developing a sensor to monitor environmental samples such as methyl parathion, paraoxon and their metabolites (Zhang et al., 2014).

\section{Nanoagroparticles in plant growth promotion and seed germination}

Sieving property of plant cell act as a barrier for foreign particles and in most cases the agrochemicals are in macro size and often are in effective. In contrast to such situation, use of nanosize particles can easily penetrate and carry out the desired activity. In recent years, use of carbon nanoparticles has influenced plant growth and development. According to study conducted by Srivastava and Rao (2014), the functionalized multiwalled carbon nanotubes were able to penetrate the seed coating and enhanced uptake of water by creating new pores. The results suggested that root and shoot growth was increased along with biomass and number of leaves compared to controlled samples.

The study also highlighted the low dosage of multiwalled carbon nanotubes influenced the growth of maize, garlic, peanut and wheat. Similarly, zinc oxide nanoparticles at low concentration of 20 and $30 \mu \mathrm{g} / \mathrm{mL}$ influenced the growth, flowering and seed productivity in onions compared to control onions (Laware and Raskar, 2014). The effect of nanocrystalline powders comprises of iron, cobalt and copper on productivity of soya beans were determined by Ngo et al. (2014). The study demonstrated pre-sowing treatment of soya bean seeds does not exert any adverse effect on the germination. The germination rate was $65 \%$ with iron nanocrystal, whereas both cobalt and copper nanocrystals showed 80\% germination rates. Apart from germination rate, these nanocrystals also increased the chlorophyll index and a number of nodules compared to control samples and overall $16 \%$ increase of crop yield was observed.

\section{Nanomaterial coated water filters}

Irrigation system plays a vital role in the agriculture. It is estimated that most of the farming communities are forced to use contaminated or cross contaminated water for agriculture practices especially in developing countries where lack of education, poor sanitary conditions and long-term droughts. The contaminated water not only affects the crop yield, it also reported to have a deleterious effect on soil fertility (Chong et al., 2010). Some of the major contaminants includes organic pollutants, inorganic compounds, heavy metals and many other complex compounds (Fatta et al., 2011). These contaminant materials which enter into the environment via wastewater may cause harmful effects to humans and ecological environment. The removal or inactivation of contaminants is often not feasible as conventional process includes chemical treatment, ultraviolet radiation, filtration and desalination which are not always available in the remote area and these methods are expensive (Zhang and Fang, 2010; Oller et al., 2011). Recently, implementation of nanoparticles in treatment of waste water is one of the potential alternatives to existing water treatment process. The nanomaterial-based technology includes a variety of membranes and filters (Fig. 5) which often consists of magnetic nanoparticles, nanoporous ceramics, carbon nanotubes, and other nanomaterials. These nanomaterials act efficiently and purify the water without usage of high-end instrumentation. The ability of 
nanoscience to solve technical challenges associated with removal of water contaminants can also benefit 'potable' water system to eliminate water borne pathogens which are one of the leading cause for microbial infections. Iron oxide nanoparticles are considered as a promising source for industrial wastewater treatment. Some of the salient features include the strong adsorption capacity, low cost, easy to separate (Girginova et al., 2010; Fan et al., 2012). Similarly magnetic nanoparticles a posses unique physiochemical properties for instance surface charge, size and paramagnetic properties which makes them one of the ideal candidate in waste water treatment (Qu et al., 2013). Further, studies also demonstrate usage of nanoparticles like alumina, silver, zinc and titanium dioxide in waste water treatment.

\section{Future prospective and conclusion}

There has been a significant progress on nanoparticles based applications in the pharmaceutical and biomedical sectors. Scanty reports are available on the appropriate usage and development of eco-friendly nanoparticles in agriculture sector. Hence implementation of nanomaterials can uplift the agriculture standards and provide benefits in different ways. But one of the major constrain is the toxicity of nanoparticles. Hence to overcome the toxic effects, different rational strategies are being designed. One such strategy involves use of biological entities or their products for production of nanoparticles which forms one of the eco-friendly processes for synthesis of nanoparticles. Further, bioconjugation and encapsulation of nanoparticles with bioactive molecules is promising field which minimize the risk of toxicity. Hence in order to gain successful usage and commercialization of nanomaterials, different expertise should collaborate to design biomimetic nanomaterials and their evaluation in agriculture sector.

\section{Acknowledgments}

Authors are thankful for Ministry of Education and Science of the Russian Federation for providing funding under 5-100: Russian Academic Excellence Project. Authors are grateful for facilities provided by Siberian Federal University.

\section{References}

Agrios, G.N., 2005. Plant Pathology. Elsevier Academic Press, San Diego, CA, USA Ali, S.M., Yousef, N.M.H., Nafady, N.A., 2015. Application of biosynthesized silver nanoparticles for the control of land snail Eobania vermiculata and some plant pathogenic fungi. J. Nanomater, 218904

Al-Othman, M.R., Abd El-Aziz, A.R.M., Mahmoud, M.A., Eifan, S.A., El-Shikh, M.S., Majrashi, M., 2014. Application of silver nanoparticles as antifungal and antiaflatoxin B1 produced by Aspergillus flavus. Dig. J. Nanomater. Biostruct. 9, 151-157.

Anand, R., Kulothungan, S., 2014. Silver mediated bacterial nanoparticles as seed dressing against crown rot pathogen of groundnut. Arch. Appl. Sci. Res. 6, 109-113. Aravinthan, A., Govarthanan, M., Selvam, K., Praburaman, L., Selvankumar, T., Balamurugan, R., Kamala-Kannan, S., Kim, J.H., 2015. Sunroot mediated synthesis and characterization of silver nanoparticles and evaluation of its antibacterial and rat and characterization of silver nanoparticles and evaluation of

splenocyte cytotoxic effects. Int. J. Nanomed. 10, 1977-1983.
Bagwea, R.P., Xiaojun, Z., Weihong, T., 2003. Bioconjugated luminescent nanoparticles Bagwea, R.P., Xiaojun, Z., Weihong, T., 2003. Bioconjugated lun

Baker, S., Harini, B.P., Rakshith, D., Satish, S., 2013a. Marine microbes: invisible Baker, S., Harini, B.P., Rakshith, D., Satis,

nanofactories. J. Pharm. Res. 6, 383-388.
Baker, S., Kumar, K.M., Santosh, P., Rakshith, D., Satish, S., 2015. Extracellular synthesis of silver nanoparticles by novel Pseudomonas veronii AS41G inhabiting Annona squamosa L. and their bactericidal activity. Spectrochim. Acta Mol. Biomol. Spectrosc. $136,1434-1440$

Baker, S., Rakshith, D., Kavitha, K.S., Santosh, P., Kavitha, H.U., Yashavantha Rao, H.C 2013b. Plants: emerging as nanofactories towards facile route in synthesis of nanoparticles. BioImpacts 3, 111-117.

Baker, S., Satish, S., 2012. Endophytes: towards a vision in synthesis of nanoparticle for future therapeutic agents. Int. J. Bio-Inorg. Hybrid Nanomater. 1, 67-77.

Baker, S., Satish, S., 2015. Biosynthesis of gold nanoparticles by Pseudomonas veronii AS41G inhabiting Annona squamosa L. Spectrochim. Acta Mol. Biomol. Spectrosc. $150,691-695$

Baker, S., Vinayaka, A.C., Manonmani, H.K., Thakur, M.S., 2013c. Development of dipstick-based immuno-chemiluminescence techniques for the rapid detection of dichlorodiphenyltrichloroethane. Luminescence 27, 524-529.

Bhardwaj, D., Ansari, M.W., Sahoo, R.K., Tuteja, N., 2014. Biofertilizers function as key player in sustainable agriculture by improving soil fertility, plant tolerance and crop player in sustainable agriculture by imp.
productivity. Microb. Cell Fact. 13, 66 . Bhor, G., Maskare, S., Hinge, S., Singh, L., Nalwade, A., 2014. Synthesis of silver nanoparticles by using leaflet extract of Nephrolepis exaltata $\mathrm{L}$. and evaluation of antibacterial activity against human and plant pathogenic bacteria. Asian J. Pharm. Technol. Innov. 02 (07), 2014.

Boro, R.C., Kaushal, J., Nangia, Y., Wangoo, N., Bhasinc, A., Suri, C.R., 2011. Gold nanoparticles catalyzed chemiluminescence immunoassay for detection of herbicide 2,4-dichlorophenoxyacetic acid. Analyst 136, 2125-2130.

Chong, M.N., Jin, B., Chow, C.W., Saint, C., 2010. Recent developments in photocatalytic water treatment technology: a review. Water. Res. 44, 2997-3027.

Chowdhury, S., Basu, A., Kundu, S., 2014. Green synthesis of protein capped silver nanoparticles from phytopathogenic fungus Macrophomina phaseolina (Tassi) Goi with antimicrobial properties against multidrug-resistant bacteria. Nanoscale Res. Lett. 9, 365

Dhekney, S., Li, A., Anaman, M., Dutt, M., Tattersall, J., Gray, D., 2007. Genetic transformation of embryogenic cultures and recovery of transgenic plants in Vitis vinifera, Vitis rotundifolia and Vitis hybrids. Acta Hortic. 738, 743-748. Diaz-Rodrigues, J.A., Antonio-Izarraras, W.M., Bandini, P., Lopez-Molina, J.A., 2008 Cyclic strength of natural liquefiable sand stabilized with colloidal silica grout. Can. Geotech. J. 45, 1345-1355.

Dubas, S.T., Pimpan, V., 2008. Humic acid assisted synthesis of silver nanoparticles and its application to herbicide detection. Mater. Lett. 62, 2661-2663.

El-Rahman, A.F.A. Mohammad, T.G.M. 2013. Green synthesis of silver nanoparticle using Eucalyptus globulus leaf extract and its antibacterial activity. J. Appl. Sci. Res. 9 (10), 6437-6440

Fan, F.L., Qin, Z., Bai, J., Rong, W.D., Fan, F.Y., Tian, W., Wu, X.L., Wang, Y., Zhao, L, Fan, F.L., Qin, Z., Bai, J., Rong, W.D., Fan, F.Y., Tian, W., Wu, X.L., Wang, Y., Zhao,
2012. Rapid removal of uranium from aqueous solutions using magnetic Fe3O4-SiO2

Fatta, K.D., Kalavrouziotis, I.K., Koukoulakis, P.H., Vasquez, M.I., 2011. The risks associated with wastewater reuse and xenobiotics in the agroecological environment. Sci. Total Environ. 409, 3555-3563

Feynman, R.P., 1960. There's plenty of room at the bottom. Eng. Sci. 23, 22-36. Fraceto, L.F., Grillo, R., de Medeiros, G.A., Scognamiglio, V., Rea, G., et al., 2016. Nanotechnology in agriculture: which innovation potential does it have? Front. Environ. Sci. 4, 20.

Gallagher, P.M., Mitchel, J.K., 2002. Influence of colloidal silica grout on liquefaction potential and cyclic undrained behaviour of loose sane. Soil Dyn. Earthq. Eng. 22, $1017-1026$.

Gill, H.K., Garg, H., 2014. Pesticides: environmental impacts and management strategies, pesticides - toxic aspects, Dr. Sonia Soloneski (Ed.). InTech. http://dx.doi.org/10. $5772 / 57399$

Girginova, P.I., Daniel-da-Silva, A.L., Lopes, C.B., Figueira, P., Otero, M., Amaral, V.S. Pereira, E., Trindade, T., 2010. Silica coated magnetite particles for magnetic removal of $\mathrm{Hg} 2+$ from water. J., Colloid Interface Sci. 345, $234-240$.

Gratchev, I.B., Sassa, K., Osipov, V.I., Fukuoka, H., Wang, G., 2007. Undrained cyclic Gratchev, I.B., Sassa, K., Osipov, V.I., Fukuoka, H., Wang, G., 2007. U

Grill, R., Pereira, A.E.S., Nishiska, C.S., Ling, R.

Fr., Fraceto, L.F., 2014. Chitosan/tripolyphosphate nanoparticles loaded with

paraquat herbicide. An environmentally safer alternative for weed control. J. Hazard. paraquat herbicide. An
Mater. 278, 163-171.

Guo, W., Nazim, H., Liang, Z., Yang, D., 2016. Magnesium deficiency in plants: an urgent problem. Crop. J. 4, 83-91.

Guyton, K.Z., Loomis, D., Grosse, Y., El Ghissassi, F., Benbrahim-Tallaa, L., Guha, N., Scoccianti, C., Mattock, H., Straif, K., 2015. Carcinogenicity of tetrachlorvinphos, parathion, malathion, diazinon, and glyphosate. Lancet Oncol. 16, 490-491. Hafez, E.E., Hassan, H.S., Elkady, M., Salama, E., 2014. Assessment of antibacterial 
activity for synthesized zinc oxide nanorods against plant pathogenic strains. Int. J. Sci. Technol. Res. 3, 318-324

Hu, R., Huang, X., Huang, J., Li, Y., Zhang, C., Yin, Y., Chen, Z., Jin, Y., Cai, J., Cui, F., 2015. Long and short term health effect of pesticides exposure: a cohort Study from China. PLOS ONE 2015, 10

Ishaaya, I., Nauen, A., Horowitz, R., 2007. Insecticides Design Using Advanced Technologies. Springer Science \& Business Media, Technology \& Engineering. Kang, J.W., 2014. Removing environmental organic pollutants with bioremediation and phytoremediation. Biotechnol. Lett. 36, 1129-1139.

Kang, T., Wang, f., Lu, L., Zhang, Y., Liu, T., 2010. Methyl parathion sensors based on gold nanoparticles and Nafion film modified glassy carbon electrodes. Sens. Actuators B nanoparticles $104-109$

Kanhed, P., Birla, S., Gaikwad, S., Gade, A., Seabra, A.B., Rubilar, O., Duran, N., Rai, M. 2014. In vitro antifungal efficacy of copper nanoparticles against selected crop

Kavitha, K.S., Baker, S., Rakshith, D., Kavitha, H.U., Yashwantha Rao, H.C., Harini, B.P. Satish, S., 2013. Plants as green source towards synthesis of nanoparticles. Int. Res. J. Biol. Sci. 2, 66-76.

Khadri, H., Alzohairy, M., Janardhan, A., Kumar, A.P., Narasimha, G., 2013. Green synthesis of silver nanoparticles with high fungicidal activity from olive seed extract. Adv. Nanopart. 2, 241-246.

Krupke, C.H., Hunt, G.J., Eitzer, B.D., Andino, G., Given, K., 2012. Multiple routes of pesticide exposure for honey bees living near agricultural fields. PLoS ONE e29268. http://dx.doi.org/10.1371/journal.pone.0029268.

Laware, S., Raskar, S., 2014. Influence of zinc oxide nanoparticles on growth, flowering and seed productivity in onion. Int. J. Curr. Microbiol. Appl. Sci. 3, 874-881.

Liu, F., Wen, L., Li, Z., Yu, W., Sun, H., Chen, J., 2006. Porous hollow silica nanoparticles as controlled delivery system for water-soluble pesticide. Mater. Res. Bull. 41, 2268-2275.

Liu, S., Yuan, L., Yue, X., Zheng, Z., Tang, Z., 2008. Recent advances in nanosensors for organophosphate pesticide detection. Adv. Powder Technol. 19, 419-441. organophosphate pesticide detection. Adv. Powder Technol. 19, 419-441. Luo, M., Lit, D., Z Zha, L., Han, J., Liang, Y., Wang, P., Zhou, Z., 2014. A novel magnetic aryloxyphenoxy-propionate herbicides and their metabolites in water. Anal. Chim. Acta 852, 88-96.

Marziye Aboli, P., Yazdan, M., Roostaei, A., Khani, M., Negahdari, M., Rahimi, G., 2014 Evaluation of the antifungal effect of magnesium oxide nanoparticles on Fusarium oxysporum F. Sp. lycopersici, pathogenic agent of tomato. Eur. J. Exp. Biol. 4 (3), $151-156$

Mba, C., Guimaraes, P., Ghosh, K., 2012. Re-orienting crop improvement for the changing climatic conditions of the 21st century. Agric. Food Secur. 1, 7 .

Medda, S., Hajra, A., Dey, U., Bose, P., Mondal, N.K., 2014. Biosynthesis of silver nanoparticles from Aloe vera leaf extract and antifungal activity against Rhizopus sp. and Aspergillus sp. Appl. Nanosci. http://dx.doi.org/10.1007/s13204-014-0387-1. Mishra, S., Singh, B.R., Singh, A., Keswani, C., Naqvi, A.H., Singh, H.B., 2014. Biofabricated silver nanoparticles act as a strong fungicide against Bipolaris sorokiniana causing spot blotch disease in wheat. PLOS ONE 9, 978-981. Morsy, M.K., Khalaf, H.H., Sharoba, A.M., El-Tanahi, H.H., Cutter, C.N., 2014 Incorporation of essential oils and nanoparticles in pullulan films to control foodborne pathogens on meat and poultry products. J. Food Sci. 79, M675-M682. Ngo, Q.B., Dao, T.H., Nguyen, H.C., Tran, X.T., Nguten, T.V., Khuu, T.D., Huynh, T.H., 2014. Effects of nanocrystalline powders ( $\mathrm{Fe}, \mathrm{Co}$ and $\mathrm{Cu}$ ) on the germination, growth, crop yield and product quality of soybean (Vietnamese species DT-51). Adv. Nat. Sci. crop yield and product quality of

Nikalje, A., 2015. Nanotechnology and its applications in medicine. Med. Chem. 15, $81-89$

Oller, I., Malato, S., Sanchez-Perez, J.A., 2011. Combination of advanced oxidation processes and biological treatments for wastewater decontamination - a review. Sci. Total Environ 409 , 4141-4166.

Ouda, S.M., 2014. Antifungal activity of silver and copper nanoparticles on two plan pathogens, Alternaria alternata and Botrytis cinerea. Res. J. Microbiol. 9, 34-42. Overbeck, S., Rink, L., Haase, H., 2008. Modulating the immune response by oral zinc supplementation: a single approach for multiple diseases. Arch. Immunol. Ther. Exp. $56,15-30$.

Parisi, C., Vigani, M., Rodríguez-Cerezo, E., 2015. Agricultural nanotechnologies: what are the current possibilities? Nano Today 10, 124-127.

Parizi, M.A., Moradpour, Y., Roostaei, A., Khani, M., Negahdari, M., Rahimi, G., 2014 Evaluation of the antifungal effect of magnesium oxide nanoparticles on Fusarium oxysporum F. Sp. lycopersici, pathogenic agent of tomato. Eur. J. Exp. Biol. 4, $151-156$

Patel, N., Desai, P., Patel, N., Jha, A., Gautam, H.K., 2014. Agronanotechnology for plan fungal disease management: a review. Int. J. Curr. Microbiol. Appl. Sci. 3, 71-84.

Paulkumar, K., Gnanajobitha, G., Vanaja, M., Rajeshkumar, S., Malarkodi, C., Pandian, K., Annadurai, G., 2014. Piper nigrum leaf and stem assisted green synthesis of silver nanoparticles and evaluation of its antibacterial activity against agricultural plant pathogens. Sci. World J. 2014, 829894.

Pereira, A.E.S., Grillo, R., Mello, N.F.S., Rosa, A.H., Fraceto, L.F., 2014. Application of poly(epsilon-caprolactone) nanoparticles containing atrazine herbicide as an alternative technique to control weeds and reduce damage to the environment. J. Hazard. Mater. 268, 207-215.

Hazard. Mater. 268, 207-215.
Porchezhiyan, V., Noorjahan, S.E., 2016. Fabrication of versatile chitosan nanocomposite Porchezhiyan, V., Noorjahan, S.E., 2016. Fabrication of versatile chitosan nan
hydrogel impregnated with biosynthesized silver nanoparticles using Sapindus hydrogel impregnated with biosynthesized silver nanoparticles using Sapin
mukorossi: characterization and applications. RSC Adv, 6, 95564-95573.

Pouratashi, M., Iravani, H., 2012. Farmers knowledge of integrated pest management and learning style preferences: implications for information delivery. Int. J. Pest Manag.

Qu, X., Alvarez, P.J.J., Li, Q., 2013. Applications of nanotechnology in water and wastewater treatment. Water Res. 47, 3931-3946.

Rabab, M.A.E., El-Shafey, R.A.S., 2013. Inhibition effects of silver nanoparticles again rice blast disease caused by Magnaporthe grisea, Egypt. J. Agric. Res. 91, 1271-1283. Ramy, S.Y., Ahmed, O.F., 2013. In vitro study of the antifungal efficacy of zinc oxide nanoparticles against Fusarium oxysporum and Penicillium expansum. Afr. J. Microbiol. Res. 7, 1917-1923.

Rao, K.J., Paria, S., 2013. Use of sulfur nanoparticles as a green pesticide on Fusarium solani and Venturia inaequalis phytopathogens. RSC Adv. 3, 10471-10478. Rouhani, M., Samih, M.A., Kalantri, S., 2012. Insecticidal effect of silica and silve nanoparticles on the cowpea seed beetle, Callosobruchus maculatus F. (Col.: Bruchidae). J. Entomol. Res. 4, 297-305.

Sabir, S., Arshad, M., Chaudhari, S.K., 2014. Zinc oxide nanoparticles for revolutionizing agriculture, synthesis and applications. Sci. World J. 2014, 1-8.

agriculture, synthesis and applications. Sci. World J. 2014, $1-8$. Sekhon, B.S., 2014. Nanotechnology in agri-food production: an overview. Nanotechnol.
Sci. Appl. 7, 31-53.

Singh, M., Pant, G., Hossain, K., Bhatia, A.K., 2016. Green remediation. Tool for safe and sustainable environment: a review. Appl. Water Sci. http://dx.doi.org/10.1007/

Srivastava, A., Rao, D.P., 2014. Enhancement of seed germination and plant growth of wheat, maize, peanut and garlic using multiwalled carbon nanotubes. Eur. Chem Bull. 3, 502-504

Syed, B., Nagendra-Prasad, M.N., Satish, S., 2016. Synthesis and characterization of silver nanobactericides produced by Aneurinibacillus migulanus 141, a novel endophyte inhabiting Mimosa pudica L. Arab. J. Chem. http://dx.doi.org/10.1016/j.arabjc.2016. 01.005

Syu, Y., Hung, J., Chen, J.C., Chuang, H., 2014. Impacts of size and shape of silver nanoparticles on Arabidopsis plant growth and gene expression. Plant Physiol. Biochem. 83, 57-64.

Teodoro, S., Micaela, B., David, K.W., 2010. Novel use of nano-structured alumina as an insecticide. Pest Manag. Sci. 66, 577-579.

Usman, M.S., El Zowalaty, M.E., Shameli, K., Zainuddin, N., Salama, M., Ibrahim, N.A., 2013. Synthesis, characterization, and antimicrobial properties of copper

nanoparticles. Int. J. Nanomed. 8, 4467-4479.

Wani, A.H., Shah, M.A., 2012. A unique and profound effect of $\mathrm{MgO}$ and $\mathrm{ZnO}$

Wani, A.H., Shah, M.A., 2012. A unique and profound effect of $\mathrm{MgO}$ and $\mathrm{ZnO}$

Yu, Z., Sun, X., Song, H., Wang, W., Ye, Z., Shi, L., Ding, K., 2015. Glutathione-responsive carboxymethyl chitosan nanoparticles for controlled release of herbicides. Mater. Sci. Appl. 6, 591-604.

Zhang, L.D., Fang, M., 2010. Nanomaterials in pollution trace detection and environmental improvement. Nano Today 5, 128-142.

Zhang, W., Asiri, A.M., Liu, D., Du, D., Lin, Y., 2014. Nanomaterial-based biosensors for environmental and biological monitoring of organophosphorus pesticides and nerve agents. Trends Anal. Chem. 54, 1-10.

Zhao, G., Song, S., Wang, C., Wu, Q., Wang, Z., 2011. Determination of triazine herbicides in environmental water samples by high-performance liquid chromatography using graphene-coated magnetic nanoparticles as adsorbent. Anal. Chim. Acta 708, $155-159$.

Zhao, L., Seth, A., Wibowo, N., Zhao, C.X., Mitter, N., Yu, C., Middelberg, A.P.J., 2014. Nanoparticle vaccine. Vaccine 32, 327-337. 
Fig. 1. Application of nanoparticles in agriculture

Fig. 2. Bioactive metabolites responsible for synthesis and stabilization of nanoparticles

Fig. 3. Bioconjugated nanoparticles and their mode of action on pathogenic bacteria.

Fig. 4. Nanoparticles based biosensors

Fig. 5. Water filters used in the irrigation system 
Table 1. Biological entities in synthesis of different types of nanoparticles

\begin{tabular}{|c|c|c|}
\hline Microorgan ism & Type of nanoparticles & Size \\
\hline \multicolumn{3}{|l|}{ Bacteria } \\
\hline Aquaspirilhon magnesotactic & $\mathrm{Fe}_{3} \mathrm{O}_{4}$ & $40-50 \mathrm{~nm}$ \\
\hline Bacilles suboilis & Au & $10 \mathrm{~nm}$ \\
\hline Corynebacterison sp. $\mathrm{SH} 09$ & $\mathrm{Ag}$ & $10-15 \mathrm{~nm}$ \\
\hline Desulfovibrio desulfuricans & $\mathrm{Pd}$ & $50 \mathrm{~nm}$ \\
\hline Escherichia coli & Au & $30-40 \mathrm{~nm}$ \\
\hline Lactobacilhes sp. & Au, Ag, Au-Ag & $20-50 \mathrm{~nm}$ \\
\hline Magnetosactic bacterium & $\mathrm{FeS}_{2}$ & $7.5 \mathrm{~nm}$ \\
\hline Pseudomonas aeroginosa & $\mathrm{Se}, \mathrm{Ag}$ & - \\
\hline Pseudomonas stutceri AG 259 & $\mathrm{Ag}$ & $<200 \mathrm{~nm}$ \\
\hline Rhodobacter capsulanus & Au & - \\
\hline \multicolumn{3}{|l|}{ Fungi } \\
\hline A.ppergillies flavus & $\mathrm{Ag}$ & $8-9 \mathrm{~nm}$ \\
\hline Aspergillis furigatus & $\mathrm{Ag}$ & $5-25 \mathrm{~nm}$ \\
\hline Aspergillis niger & Ag & $20 \mathrm{~nm}$ \\
\hline Colletotricham sp. & Au & $20-40 \mathrm{~nm}$ \\
\hline Coniolus versicolor & $\mathrm{Ag}$ & $25-75 \mathrm{~nm}$ \\
\hline Fusariam oxysporzen & CdSe & $9-15 \mathrm{~nm}$ \\
\hline Fusarion acuminatum & $\mathrm{Ag}$ & $5-40 \mathrm{~nm}$ \\
\hline Fusarian oxysporien & $\mathrm{Bi}_{2} \mathrm{O}_{3}$ & $5-8 \mathrm{~nm}$ \\
\hline Fusariem oxysporien f. sp. lycopersici & Pt & $10-50 \mathrm{~nm}$ \\
\hline Fusariom semitecnom & $\mathrm{Ag}$ & $10-60 \mathrm{~nm}$ \\
\hline Fusariem solani & $\mathrm{Ag}$ & $16-20 \mathrm{~nm}$ \\
\hline \multicolumn{3}{|l|}{ Actinomy cetes } \\
\hline Rhodococcus sp. & Au & $5-15 \mathrm{~nm}$ \\
\hline Themonospora sp. & Au & $8 \mathrm{~nm}$ \\
\hline \multicolumn{3}{|l|}{ Yeasts } \\
\hline P. jadinili & Au & $100 \mathrm{~nm}$ \\
\hline Saccharomyces cerevisiae & $\mathrm{Sb}_{2} \mathrm{O}_{3}$ & $3-10 \mathrm{~nm}$ \\
\hline Schizosaccharanyces pombe & Cds & $1-1.5 \mathrm{~nm}$ \\
\hline Yarrowia Ipolytica & Au & $15 \mathrm{~nm}$ \\
\hline Yeast MKY3 & $\mathrm{Ag}$ & $2-5 \mathrm{~nm}$ \\
\hline Candida glabrata & Pbs & $<1 \mathrm{~nm}$ \\
\hline \multicolumn{3}{|l|}{ Algae } \\
\hline Sargassum algae & $\mathrm{SiO}_{2}$ & $50-100 \mathrm{~nm}$ \\
\hline Shewanella algae & Au & $10-20 \mathrm{~nm}$ \\
\hline \multicolumn{3}{|l|}{ Plant species } \\
\hline Acalypha indica & Silver & $20-30 \mathrm{~nm}$ \\
\hline Apin extracted from benna leaves & Silver and gold & $39 \mathrm{~nm}$ \\
\hline Azadrachta indica & Gold and silver & $5-35 \mathrm{~nm}$ \\
\hline Brassica jencea & Silver & $2-35 \mathrm{~nm}$ \\
\hline Camellia sinensis (green tea) & Gold & $40 \mathrm{~nm}$ \\
\hline Cinnamomuan camphara & Silver and gold & $55-80 \mathrm{~nm}$ \\
\hline Cigus sinensis & Silver & $50 \mathrm{~nm}$ \\
\hline Emblica offacinalis & Gold and silver & $10-20 \mathrm{~nm}$ \\
\hline Eucalyptus cirriodora & Silver & $20 \mathrm{~nm}$ \\
\hline Eupharbia hirsa L. & Silver & $20 \mathrm{~nm}$ \\
\hline Garcinia mangastana & Silver & $35 \mathrm{~nm}$ \\
\hline Gardenia jasminoides Ellis & Palladium & \\
\hline Hydrila sp. & Silver & $2-5 \mathrm{~nm}$ \\
\hline Ipomoed aquatica & Silver & $100 \mathrm{~nm}$ \\
\hline Ludwigia adscendens & Silver & $100 \mathrm{~nm}$ \\
\hline Medica savisa & Iron oxide & $2-10 \mathrm{~nm}$ \\
\hline Moringa oleifera & Silver & $57 \mathrm{~nm}$ \\
\hline Neriam indicaon & Silver & \\
\hline Ocimuen basilicum & Gold & $30 \mathrm{~nm}$ \\
\hline Pelargonium graveolens & Silver & $16-40 \mathrm{~nm}$ \\
\hline Syzygiom aromaticum & Gold & $5-100 \mathrm{~nm}$ \\
\hline Tamarindus indica & Gold & $20-40$ \\
\hline Tenninalia catappa & Gold & $10-35$ \\
\hline Trichoderma koningii & Silver & $30-40$ \\
\hline
\end{tabular}


Table 2. Different types of nanoparticles and their application in agriculture

\begin{tabular}{|c|c|c|c|}
\hline $\begin{array}{l}\text { Type of } \\
\text { nanoparticles }\end{array}$ & $\begin{array}{l}\text { Mode of } \\
\text { synthesis }\end{array}$ & Application & References \\
\hline \multicolumn{4}{|c|}{ Nanoparticles in crop protection } \\
\hline Silver & Biological & F ungicidal & $\begin{array}{l}\text { Khadri et al. } \\
(2013)\end{array}$ \\
\hline Copper & Chemical & Fungicidal & $\begin{array}{l}\text { Kanbed et al. } \\
(2014)\end{array}$ \\
\hline Copper and silver & Chemical & Fungicidal & Ouda (2014) \\
\hline Silver & Biological & Bactericidal & $\begin{array}{l}\text { El-Rahman and } \\
\text { Mohammad } \\
\text { (2013) }\end{array}$ \\
\hline Zinc oxide & Chemical & Bactericidal & Hafez et al. (2014) \\
\hline \multicolumn{4}{|c|}{ Nanoparticles in seed treatment } \\
\hline Silver & Biological & Seed dressing & $\begin{array}{l}\text { Anand and } \\
\text { Kulothungan } \\
\text { (2014) }\end{array}$ \\
\hline Silver & Biological & $\begin{array}{l}\text { Surface sterilizer of } \\
\text { seed crops }\end{array}$ & $\begin{array}{l}\text { Morsy et al. } \\
(2014)\end{array}$ \\
\hline \multicolumn{4}{|c|}{ Nano-formulation as nanoherbicides, nanopesticides } \\
\hline $\begin{array}{l}\text { Polyepsilon- } \\
\text { caprolactone }\end{array}$ & Chemical & Herbicidal & $\begin{array}{l}\text { Pereira et al. } \\
(2014)\end{array}$ \\
\hline Chitosan & Chemical & Herbicidal & Grillo et al. (2014) \\
\hline $\begin{array}{l}\text { Carboxymethyl } \\
\text { chitosan }\end{array}$ & Chemical & Herbicidal & Yu et al. (2015) \\
\hline Silver & Biological & Pesticidal & Ali et al. (2015) \\
\hline \multicolumn{4}{|c|}{ Nanoparticles in biosensing } \\
\hline Carbon & Chemical & Herbicide detection & Luo et al. (2014) \\
\hline Graphene & Chemical & Herbicide detection & Zhao et al. (2011) \\
\hline Gold & Chemical & Herbicide detection & Boro et al. (2011) \\
\hline Silver & Chemical & Herbicide detection & $\begin{array}{l}\text { Dubas and Pimpan } \\
(2008)\end{array}$ \\
\hline Gold & Chemical & $\begin{array}{l}\text { Organophosphates } \\
\text { detection }\end{array}$ & Kang et al. (2010) \\
\hline \multicolumn{4}{|c|}{ Nanoparticles in plant growth promotion } \\
\hline Silver & Chemical & Plant growth & Syu et al. (2014) \\
\hline Zinc oxide & Chemical & $\begin{array}{l}\text { Flowering and seed } \\
\text { productivity }\end{array}$ & $\begin{array}{l}\text { Laware and } \\
\text { Raskar }(2014)\end{array}$ \\
\hline Iron, cobalt, copper & Chemical & $\begin{array}{l}\text { Increased germination } \\
\text { rate }\end{array}$ & Ngo et al. (2014) \\
\hline
\end{tabular}




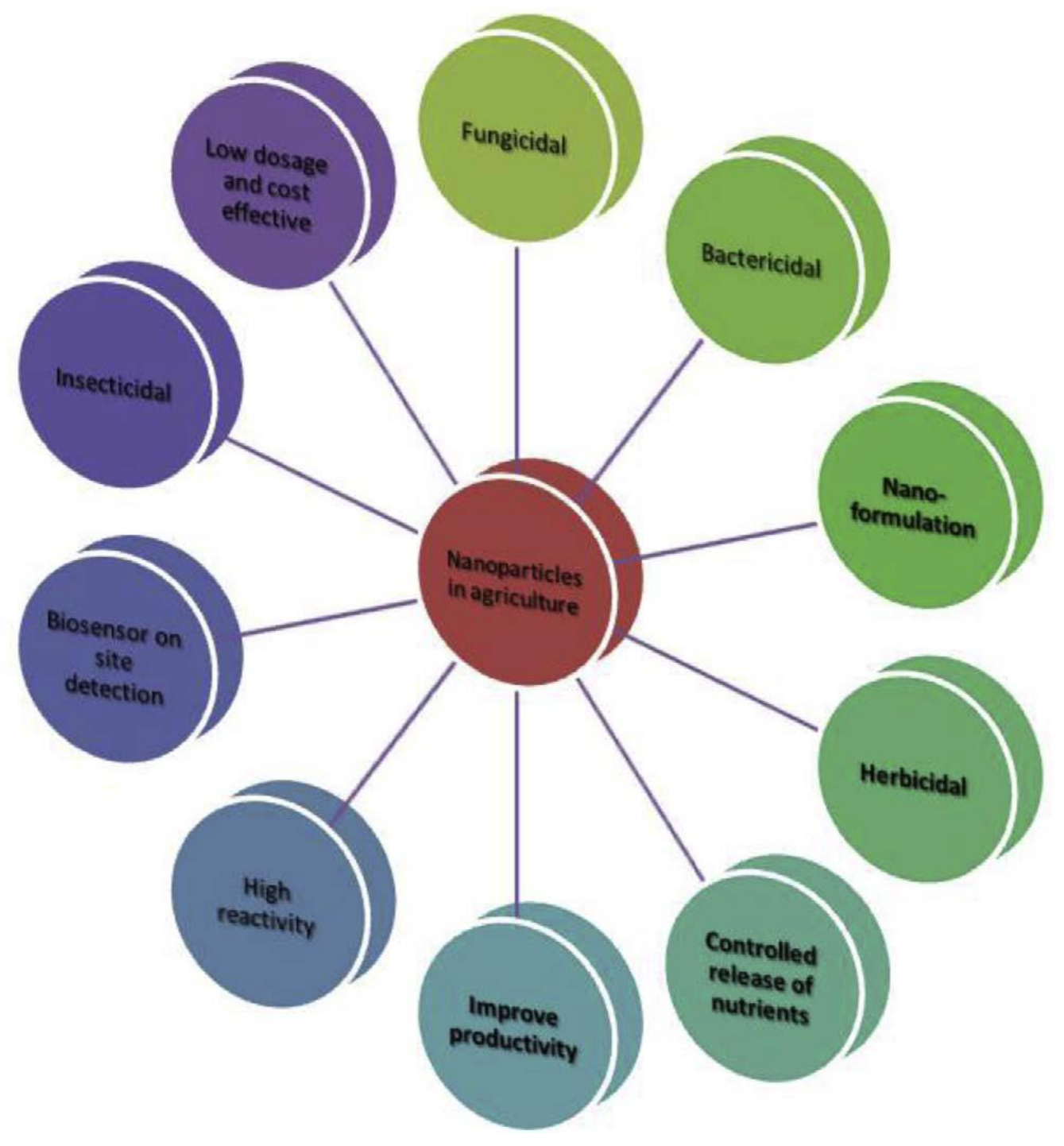




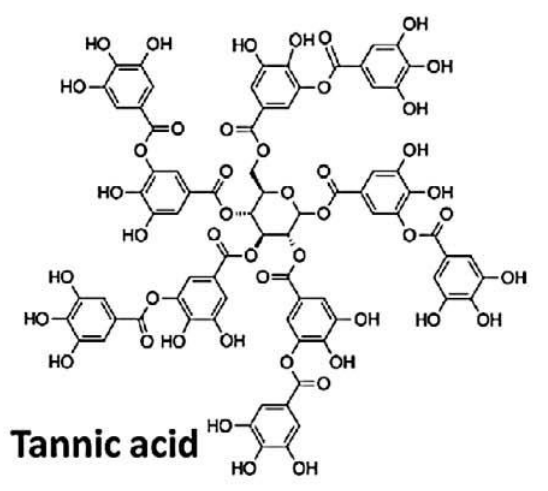<smiles>N[C@@H](Cc1c[nH]c2ccccc12)C(=O)O</smiles>

tryptophan<smiles>O=C(O)c1ccc(O)c(O)c1</smiles>

Protocatechuic_acid<smiles>O=c1cc(-c2ccc(O)c(O)c2)oc2cc(O)cc(O)c12</smiles>

Luteolin<smiles>C=CCc1ccc(O)c(OC)c1</smiles><smiles>N[C@@H](CS)C(=O)O</smiles>

L-cysteine<smiles>O=c1c(O)c(-c2ccc(O)c(O)c2)oc2cc(O)cc(O)c12</smiles><smiles>O=C1O[C@H]([C@@H](O)CO)C(O)=C1O</smiles>

Ascorbic acid<smiles>NCCCC[C@H](N)C(=O)O</smiles>

L-lysine 
Bioconjugation of nanoparticles with drug molecule

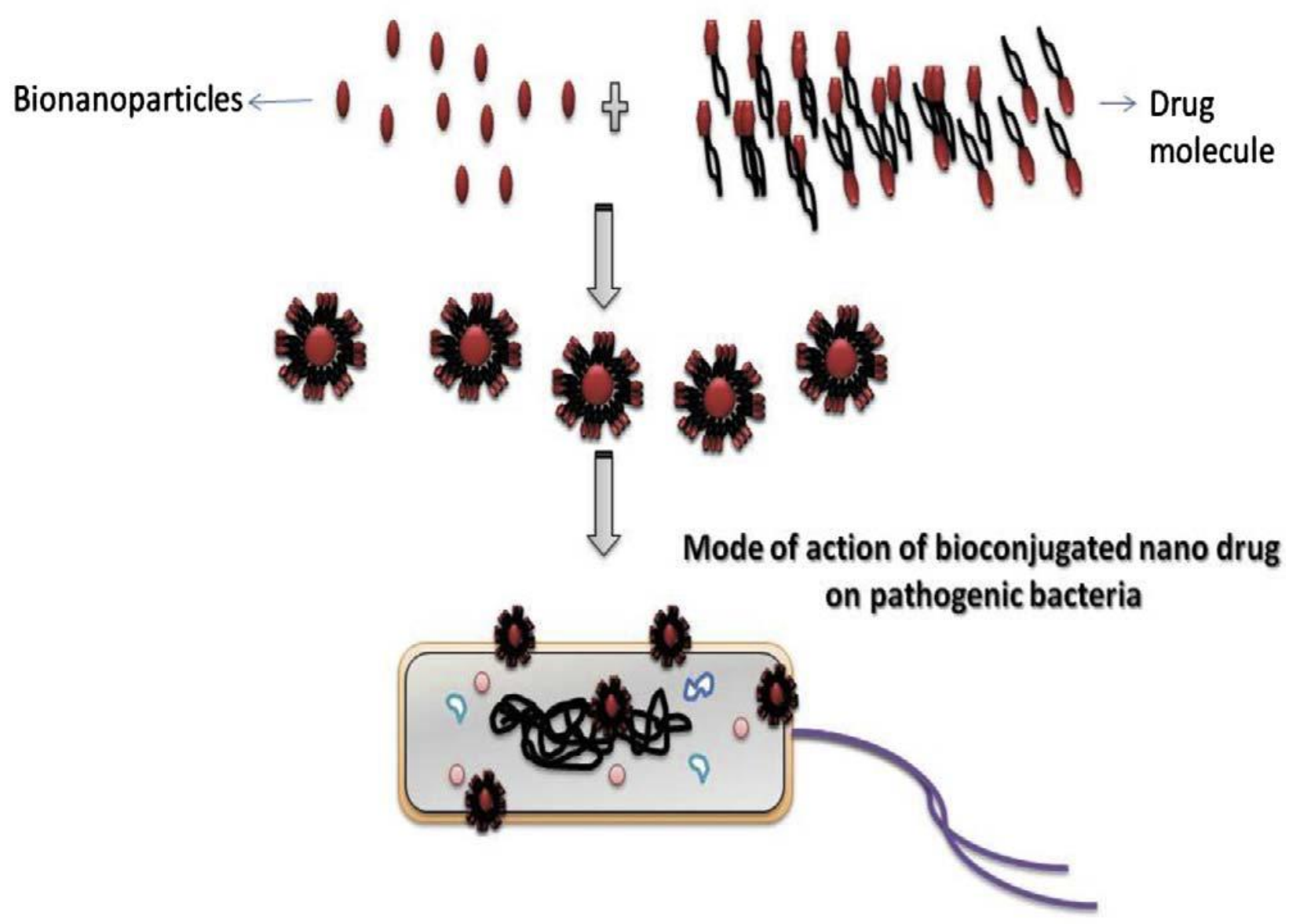




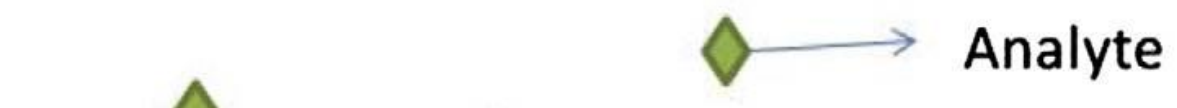
$\Delta \diamond \diamond \diamond \diamond \diamond$
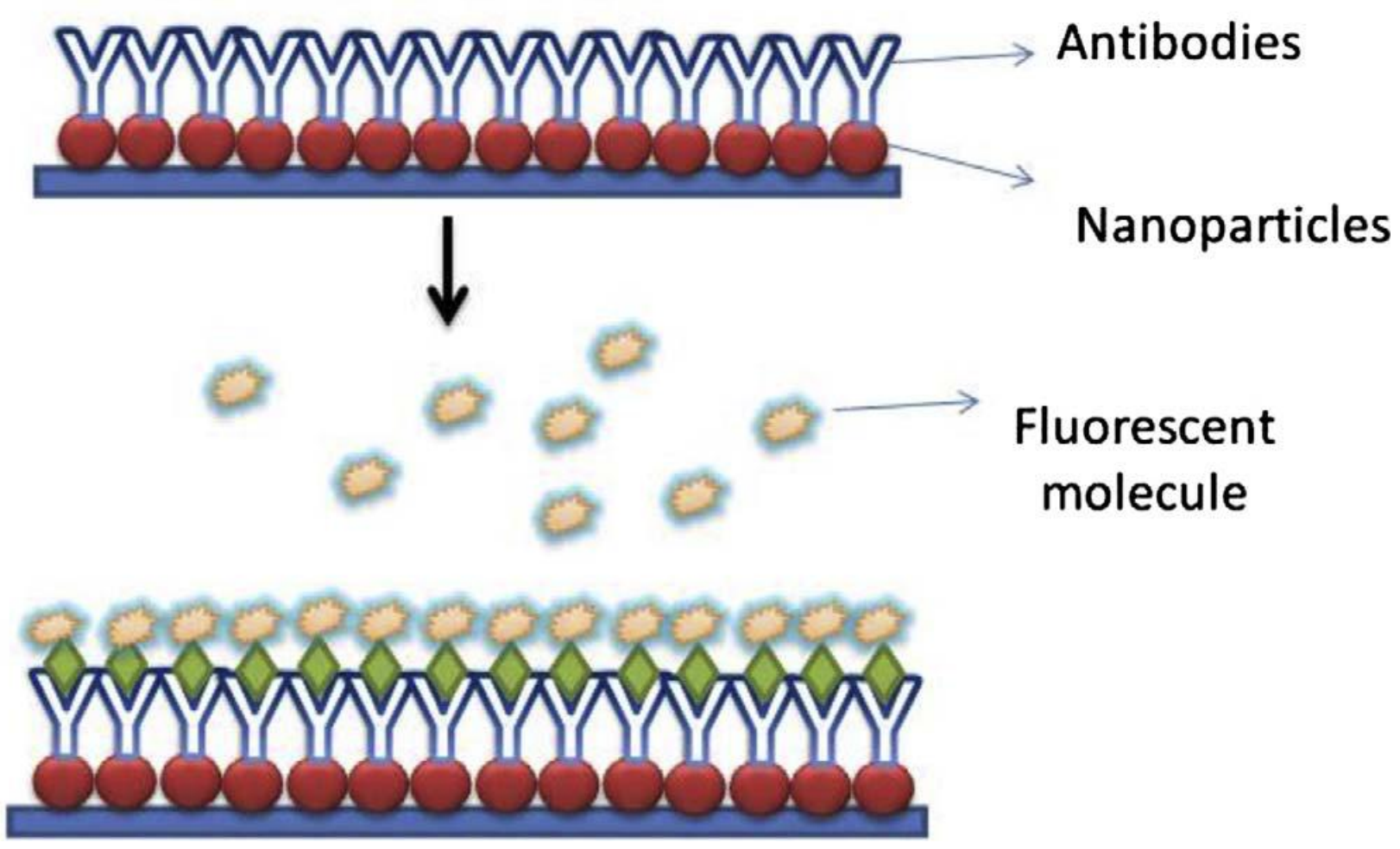


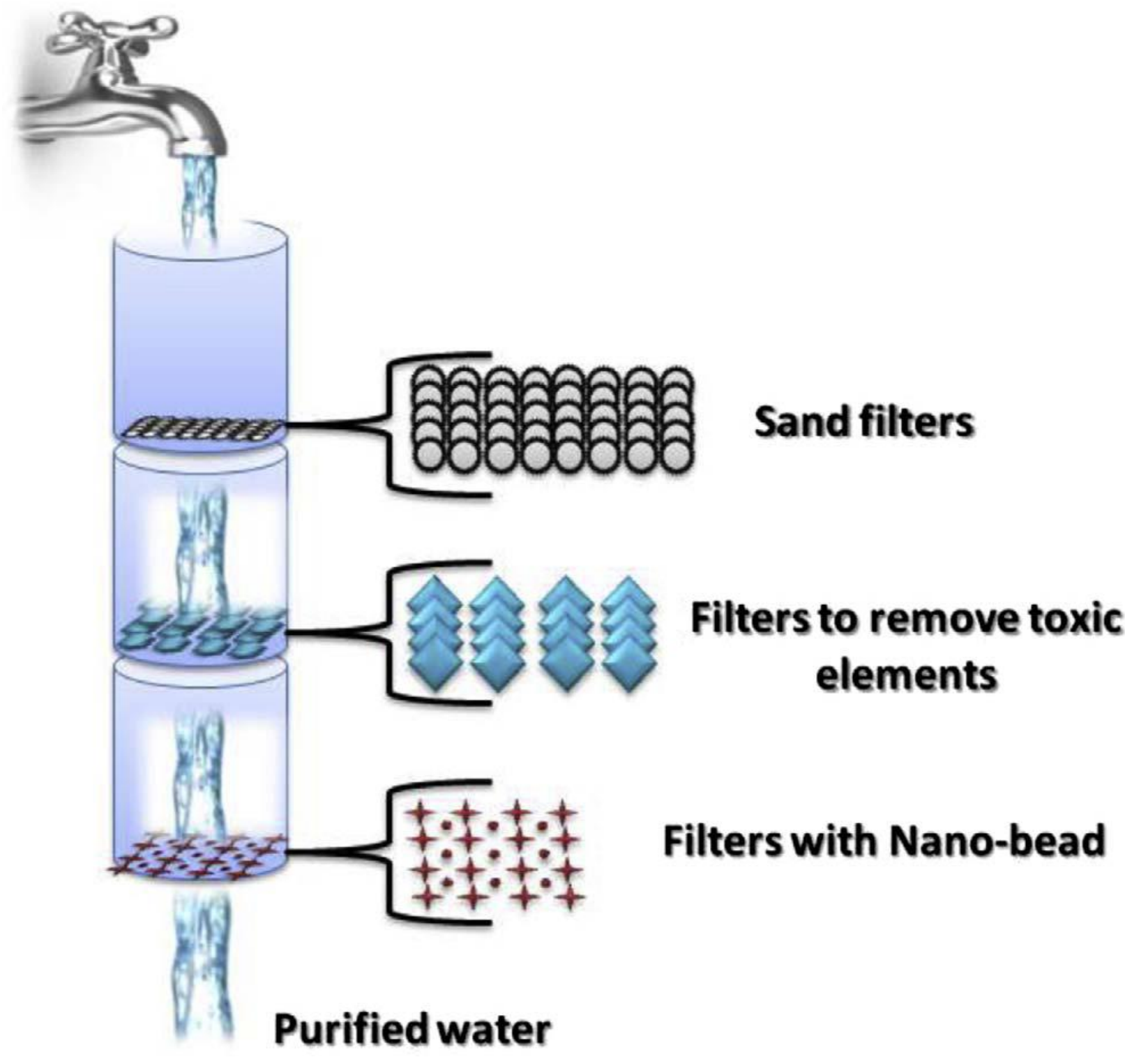

